ORIGINAL ARTICLE

\title{
Growth, mineral nutrition, and physiological parameters of Eucalyptus urophylla cultivated in soils with different nutrient reserves
}

\author{
Crescimento, nutrição mineral e parâmetros fisiológicos do Eucalyptus urophylla \\ cultivado em solos com diferentes reservas nutricionais
}

Francisco Hélcio Canuto Amaral ${ }^{1}$ (1) , Antonio Eduardo Furtini Neto ${ }^{2}$ (), Elias Frank de Araújo ${ }^{3}$, Alberto Vasconcellos Inda ${ }^{4}$ (B), Marcelo Mancini ${ }^{1}$ (D), Nilton Curi ${ }^{1}$ (D)

${ }^{1}$ Universidade Federal de Lavras - UFLA, Lavras, MG, Brasil

${ }^{2}$ Instituto Tecnológico Vale Desenvolvimento Sustentável - ITV, Belém, PA, Brasil

${ }^{3} \mathrm{CMPC}$ Celulose Riograndense, Guaíba, RS, Brasil

${ }^{4}$ Universidade Federal do Rio Grande do Sul - UFRS, Porto Alegre, RS, Brasil

\begin{abstract}
How to cite: Amaral, F. H. C., Furtini Neto, A. E., Araújo, E. F., Inda, A. V., Mancini, M., \& Curi, N. (2020). Growth, mineral nutrition, and physiological parameters of Eucalyptus urophylla cultivated in soils with different nutrient reserves. Scientia Forestalis, 48(125), e3199. https://doi.org/10.18671/scifor.v48n125.02
\end{abstract}

\begin{abstract}
Knowledge on the plant's nutrient use efficiency and physiological processes is important and can aid in choosing the species, as well as in the forest management for each soil and region. This study had the objectives of evaluating the initial growth, nutrition and physiological aspects of eucalypt cultivated with and without the addition of mineral sources of potassium (K), calcium (Ca), and magnesium (Mg). The study was performed in the Universidade Federal de Lavras (UFLA) with soils obtained from forest sites located at the geomorphologic provinces of the Peripheral Depression on the Sul-Riograndense shield and Coastal Plain of Rio Grande do Sul, Brazil. Growth variables, nutritional aspects, photosynthetic rate $(A)$ and transpiration rate $(E)$ of plants grown in distinct soils were evaluated under controlled conditions. Plants cultivated in soils presenting larger reserves and availability of $\mathrm{K}, \mathrm{Ca}$, and $\mathrm{Mg}$, showed similar height $(\mathrm{H})$, stem diameter (SD) and shoot dry matter (SDM), both with and without fertilization with $\mathrm{K}, \mathrm{Ca}$, and $\mathrm{Mg}$. Conversely, plants cultivated in soils deprived of these nutrients presented substantial improvement in these attributes in the fertilized samples of these soils. Plants presented higher leaf content and accumulation of $\mathrm{K}$ in all soils fertilized with $\mathrm{K}, \mathrm{Ca}$, and $\mathrm{Mg}$. However, overall $\mathrm{K}$ use efficiency was superior in plants cultivated in soils without fertilization. Similar results with and without fertilization in soils with larger mineral reserves demonstrate the importance of understanding soil and plant properties in order to optimize fertilization practices.
\end{abstract}

Keywords: Forest activity; Planted forest; Forest production.

\section{Resumo}

O conhecimento sobre a eficiência no uso de nutrientes e processos fisiológicos da planta é importante e pode auxiliar na escolha das espécies e do manejo florestal. Este estudo teve como objetivos avaliar o crescimento inicial, nutrição e aspectos fisiológicos do eucalipto cultivado, com e sem adição de fontes minerais de potássio $(\mathrm{K})$, cálcio $(\mathrm{Ca})$ e magnésio $(\mathrm{Mg})$. O estudo foi conduzido na Universidade Federal de Lavras (UFLA) utilizando-se solos obtidos de áreas florestais localizadas nas províncias geomorfológicas da Depressão Periférica, do escudo Sul-Riograndense e da Planície Costeira do estado do Rio Grande do Sul, Brasil. Variáveis de crescimento, aspectos nutricionais, taxa fotossintética (A) e taxa de transpiração (E) de plantas cultivadas em solos distintos, foram avaliadas sob condições controladas. Plantas cultivadas em solos com maiores reservas e disponibilidade de $\mathrm{K}, \mathrm{Ca}$ e $\mathrm{Mg}$, tiveram

Financial support: CNPq: 303840/2014-5, CAPES: 1406128/2014-6.

Conflict of interest: Nothing to declare.

Corresponding author: ntcuri@gmail.com

Received: 29 November 2018.

Accepted: 13 June 2019.

Editor: Francides Gomes da Silva Júnior.

(c) This is an Open Access article distributed under the terms of the Creative Commons Attribution License, which permits unrestricted use,

c) distribution, and reproduction in any medium, provided the original work is properly cited. 
altura $(\mathrm{H})$, diâmetro do caule (SD) e massa seca da parte aérea (SDM) semelhantes, tanto com quanto sem adubação com K, Ca e Mg. Plantas cultivadas em solos deficientes em relação a estes nutrientes tiveram um aumento nestes atributos, nas amostras adubadas destes solos. As plantas tiveram maior teor foliar e acúmulo de $\mathrm{K}$ em todos os solos adubados com K, Ca e Mg. No entanto, a eficiência de utilização deste nutriente foi superior em plantas cultivadas em solos sem fertilização. Resultados similares com e sem adubação em solos com maior reserva mineral demonstram a importância de entender as propriedades do solo e das plantas para otimizar as práticas de aplicação de fertilizantes.

Palavras-chave: Atividade florestal; Floresta plantada; Produção florestal.

\section{INTRODUCTION}

Eucalypt production is a strategic activity for social, economic and sustainable development of Brazilian agribusiness, which is in the interest of many segments of the productive chain of planted trees, especially service providers, the industry segment and input suppliers. Obtaining economically feasible forest productivity depends on many factors, such as nutrient balance in the soil-plant system (Leite et al., 2010), plant capacity for absorbing and using nutrients (Amaral et al., 2011) and soil mineral reserves, which constitute nutrient sources (Castro et al., 2010; Andrade et al., 2011; Alves et al., 2013; Amaral et al., 2015).

Knowledge about the processes which underlie these factors, such as physiological processes, is important and can aid in choosing the species, as well as in the forest management for each soil and region (Caldeira et al., 2004), optimizing the genotypeenvironment interaction. Understanding these mechanisms would allow one to adopt better plantation strategies according to soil fertility potential (Lima et al., 2005) and to obtain optimal and sustainable production even under conditions of low nutrient availability in the soil (Faria et al., 2008).

Nutrient use efficiency, plant physiology, and macronutrient release kinetics are some of the processes related to the aforementioned factors which hold a close relationship to the growth and productivity of eucalypt plantation. Castro et al. (2010) verified that the mean annual increment (MAI) of eucalypt varied according to the total content of $\mathrm{Ca}$ and $\mathrm{Mg}$ and mineralogy of distinct soils, pointing out that knowledge on the chemical and mineralogical soil traits are crucial when studying this matter.

Given the importance of understanding such mechanisms in order to optimize productivity, this study aims to evaluate initial growth, nutrition and physiological parameters of eucalypt clones, cultivated with and without the addition of mineral sources of potassium $(\mathrm{K})$, calcium (Ca), and magnesium ( $\mathrm{Mg}$ ) in soils obtained from forest sites with distinct nutrient reserves.

\section{MATERIAL AND METHODS}

\section{Study Area}

The study was conducted under greenhouse conditions at the Department of Soil Sciences (DSC) of the Universidade Federal de Lavras (UFLA), Lavras, Minas Gerais State, Brazil. The plants were cultivated in samples of seven soils (Table 1) obtained in areas commercially cultivated with Eucalyptus sp., located in the regions of geomorphologic region of the Peripheral Depression in the Sul-Riograndense shield and the Coastal Plain of Rio Grande do Sul, belonging to Celulose Riograndense Ltda - CMPC. According to Köppen's classification system (Köppen, 1931), the climate in the region is predominantly Cfa, characterized by warm, dry summers and cold, wet winters and with a mean annual rainfall of 1,500 mm. 
Table 1. Acronyms, classification and geographic coordinates of soil samples where Eucalyptus sp. clones were cultivated, collected at the state of Rio Grande do Sul, Brazil.

\begin{tabular}{ccc}
\hline Acronym & Soil Class & Geographic coordinates \\
\hline PVd & Dystrophic Red Argisol & $30^{\circ} 04^{\prime} 16,71^{\prime \prime} \mathrm{S}^{\prime}-51^{\circ} 45^{\prime} 47,72^{\prime \prime} \mathrm{W}^{2}$ \\
PVAd & Dystrophic Red-Yellow Argisol & $30^{\circ} 03^{\prime} 28,53^{\prime \prime} \mathrm{S}-51^{\circ} 46^{\prime} 10,27^{\prime \prime} \mathrm{W}$ \\
PAd & Dystrophic Yellow Argisol & $30^{\circ} 03^{\prime} 28,53^{\prime \prime} \mathrm{S}-51^{\circ} 45^{\prime} 40,00^{\prime \prime} \mathrm{W}$ \\
CXve & Eutrophic Haplic Cambisol & $30^{\circ} 30^{\prime} 59,07^{\prime \prime} \mathrm{S}-54^{\circ} 02^{\prime} 35,28^{\prime \prime} \mathrm{W}$ \\
RRd & Dystrophic Regolitic Neosol & $30^{\circ} 31^{\prime} 22,41^{\prime \prime} \mathrm{S}-54^{\circ} 03^{\prime} 46,11^{\prime \prime} \mathrm{W}$ \\
MTo & Orthic Argiluvic Chernosol & $30^{\circ} 32^{\prime} 40,81^{\prime \prime} \mathrm{S}-54^{\circ} 02^{\prime} 34,67^{\prime \prime} \mathrm{W}$ \\
RQo & Orthic Quartzarenic Neosol & $30^{\circ} 24^{\prime} 00,00^{\prime \prime} \mathrm{S}-51^{\circ} 08^{\prime} 21,00^{\prime \prime} \mathrm{W}$ \\
\hline
\end{tabular}

${ }^{1}=$ Latitude South; $^{2}=$ Longitude West.

\section{Soil Samples and Clone Transplantation}

The soil samples were collected at 0-0.20 m depth, in open trenches with representative profiles of each soil class. For each soil class, one aliquot was removed for characterization (Table 2). The soils were classified according to the Brazilian Soil Classification System, with classes described up to the third category level (Empresa Brasileira de Pesquisa Agropecuária, 2013).

Table 2. Chemical attributes and particle size distribution at depth $0.0-0.20 \mathrm{~m}$ of the seven soil classes used in the study.

\begin{tabular}{ccccccccc}
\hline \multirow{2}{*}{ Attributes } & \multirow{2}{*}{ Units } & \multicolumn{7}{c}{ Soil Classes } \\
\cline { 3 - 8 } & & PVd & PVAd & PAd & CXve & RRd & MTo & RQo \\
\hline $\mathrm{pH}$ & - & 5.5 & 5.5 & 5.2 & 5.3 & 5.1 & 5.7 & 5.8 \\
$\mathrm{~K}$ & $\mathrm{mg} \mathrm{dm}^{-3}$ & 119.7 & 43.3 & 39.3 & 95.7 & 139.1 & 122.8 & 40.5 \\
$\mathrm{P}$ & $\mathrm{mg} \mathrm{dm}^{-3}$ & 44.4 & 61.9 & 46.9 & 32.8 & 70.9 & 48.3 & 100.1 \\
$\mathrm{Ca}$ & $\mathrm{cmol}_{\mathrm{c}} \mathrm{dm}^{-3}$ & 1.9 & 0.9 & 1.3 & 3.3 & 0.7 & 4.3 & 0.6 \\
$\mathrm{Mg}$ & $\mathrm{cmol}_{\mathrm{c}} \mathrm{dm}^{-3}$ & 0.7 & 0.6 & 0.6 & 4.0 & 0.5 & 1.6 & 0.2 \\
$\mathrm{SB}$ & $\mathrm{cmol}_{\mathrm{c}} \mathrm{dm}^{-3}$ & 5.1 & 3.1 & 2.9 & 6.2 & 1.9 & 10.9 & 1.0 \\
$\mathrm{~T}$ & $\mathrm{cmol}_{\mathrm{c}} \mathrm{dm}^{-3}$ & 9.1 & 5.4 & 8.2 & 9.4 & 6.3 & 17.3 & 2.6 \\
$\mathrm{~V}$ & $\%$ & 55.6 & 57.1 & 39.8 & 65.6 & 29.4 & 63.3 & 37.9 \\
$\mathrm{~K}-\mathrm{R}$ & $\mathrm{mg} \mathrm{dm}^{-3}$ & $1,826.3$ & $1,133.2$ & 884.8 & $4,339.6$ & $2,826.9$ & $4,087.6$ & 754.4 \\
Ca-R & $\mathrm{cmol}_{\mathrm{c}} \mathrm{dm}^{-3}$ & 4.1 & 2.4 & 2.3 & 6.8 & 1.6 & 8.1 & 0.9 \\
Mg-R & $\mathrm{cmol}_{\mathrm{c}} \mathrm{dm}^{-3}$ & 5.1 & 2.2 & 1.2 & 8.2 & 1.5 & 19.9 & 0.9 \\
Clay & $\%$ & 20 & 23 & 26 & 27 & 12 & 21 & 3 \\
Silt & $\%$ & 18 & 7 & 26 & 22 & 12 & 20 & 3 \\
Sand & $\%$ & 62 & 70 & 48 & 51 & 76 & 59 & 94 \\
\hline
\end{tabular}

Attributes $\mathrm{pH}$, available phosphorous $(\mathrm{P})$ and potassium $(\mathrm{K})$ extracted per Mehlich-1 solution, exchangeable calcium and magnesium ( $\mathrm{Ca}$ and $\mathrm{Mg}$ ) extracted per $\mathrm{KCl} 1 \mathrm{~mol} \mathrm{~L}^{-1}$ solution, were determined as described by Empresa Brasileira de Pesquisa Agropecuária (2009). Potassium reserves (K-R), calcium reserves (Ca-R) and magnesium reserves (Mg-R) correspond to the total contents and were determined according to Vettori (1969). Analytical procedures were described per Amaral (2016).

Eucalypt clones were cultivated in pots for a period of six months. Clones were obtained from Eucalyptus urophylla, with the code name of AEC 1528. Treatments comprised seven soil classes and two levels of fertilization (with and without the addition of $\mathrm{K}, \mathrm{Ca}$, and $\mathrm{Mg}$ ), arranged in a $7 \times 2$ factorial scheme, using a completely randomized design with five replicates and one 
plant per pot. The supplement of $\mathrm{K}\left(300 \mathrm{mg} \mathrm{dm}^{-3}\right), \mathrm{Ca}\left(75 \mathrm{mg} \mathrm{dm}^{-3}\right)$, and $\mathrm{Mg}\left(75 \mathrm{mg} \mathrm{dm}^{-3}\right)$ was conducted via solution, according to Malavolta (1980).

To install the trial, we initially transferred three $\mathrm{dm}^{3}$ of soil (sieved at $2 \mathrm{~mm}$ ) to polypropylene pots. The micronutrients (boron, copper, iron, manganese, and zinc), and macronutrients (nitrogen, phosphorus, potassium, calcium, magnesium, and sulfur) were added via solution, with dosages as recommended by Malavolta (1980). The soils were incubated for a period of 15 days before clone transplantation in order to promote nutrients reaction and homogenization throughout the soil. The fertilization of $\mathrm{N}$ (source: urea) and $\mathrm{K}$ (source: potassium chloride) was divided into four applications of $75 \mathrm{mg} \mathrm{dm}^{-3}$, with one application performed every 15 days. In the first application of $\mathrm{K}\left(75 \mathrm{mg} \mathrm{dm}^{-3}\right)$, a complete dose of Ca (source: calcium carbonate), and Mg (source: magnesium carbonate) was provided combined with the micronutrients and remaining macronutrients in the same solution.

Clone transplantation was done 15 days after soil incubation, using a single plant in the central region of each pot. The employed clones were 75 days old and averaged $0.2 \mathrm{~m}$ height. The replacement of evaporated and transpired moisture was performed daily, using enough deionized water sufficient to maintain approximately $60 \%$ of field capacity. At the end of the cultivation period, growth and physiological variables, as well as the nutrients' content of the plants' tissue were evaluated.

\section{Biometric Variables}

The evaluated biometric variables measured were plant height $(\mathrm{H})$ and stem diameter (SD) $10 \mathrm{~cm}$ distant from the base, at the end of the cultivation period. The plants were cut and separated into shoot and root (the roots were washed in purified water); then, the separated material was dried at $65^{\circ} \mathrm{C}$. Plant production of shoot (SDM), root (RDM), and total dry matter (TDM) was then quantified.

\section{Nutritional Variables}

In the shoot dry matter (SDM), the concentrations of $\mathrm{K}, \mathrm{Ca}$, and $\mathrm{Mg}$ were determined according to analytical procedures described by Empresa Brasileira de Pesquisa Agropecuária (2009), performing the digestion of the material with nitro-perchloric solution in the proportion 2 to 1 . The concentration of $\mathrm{K}, \mathrm{Ca}$, and $\mathrm{Mg}$ in the plant was determined by atomic absorption (AA).

From the evaluated variables, accumulation of $\mathrm{K}(\mathrm{AK}), \mathrm{Ca}(\mathrm{ACa})$, and $\mathrm{Mg}(\mathrm{AMg})$ of the shoot dry matter were calculated according to the equation: nutrient accumulation $\left(\mathrm{g} \mathrm{plant}^{-1}\right)=(\mathrm{SDM}$ * nutrient content in the plant $\left.) / 1000\right)$. Additionally, the use efficiency of $\mathrm{K}$ (KUE), $\mathrm{Ca}$ (CaUE), and $\mathrm{Mg}$ (MgUE) was calculated according to the equation: use efficiency $=$ (total dry matter (g) / nutrient accumulation (g)).

\section{Physiological Parameters Variables}

The physiological parameters were measured on the same day when the material was harvested, between 9:00 and 11:00 a.m., on completely expanded leaves from the median part of the shoot, evaluating photosynthetic rate $(A)$ and transpiration rate $(E)$ with the aid of the Infra-Red Gas Analyzer - IRGA equipment, model LI6400-XT.

\section{Statistical Analysis}

The obtained data was submitted to the analysis of variance and $\mathrm{F}$ test. The treatments' means were grouped and analyzed per the Scott-Knott test, at a level of 5\% probability. When significant interactions occurred between treatments, the treatments with and without $\mathrm{K}, \mathrm{Ca}$, and $\mathrm{Mg}$ for each soil were split. All analyses were performed using the Sisvar statistical program 5.4 (Ferreira, 2014). The variables were also submitted to principal component analysis (PCA). 


\section{RESULTS AND DISCUSSION}

According to the analysis of variance (Table 3), significant interactions between treatments were observed for the variables height $(H)$, stem diameter (SD), foliar concentrations of potassium (foliar K), calcium (foliar Ca), potassium (KA), calcium (CaA) accumulation, CaUE, MgUE, and net photosynthesis (A). For the remaining variables, the effects between treatments were individual.

Table 3. Square sum of the analysis of variance for: height $(H)$; stem diameter (SD); shoot dry matter (SDM); root dry matter (RDM); total dry matter (TDM); photosynthetic rate (A); transpiration rate (E); foliar concentration of $\mathrm{K}, \mathrm{Ca}$, and $\mathrm{Mg}(\mathrm{K}, \mathrm{Ca}$, and $\mathrm{Mg})$; accumulation of $\mathrm{K}, \mathrm{Ca}$, and $\mathrm{Mg}(\mathrm{KA}, \mathrm{CaA}$, and $\mathrm{MgA})$; and use efficiency of $\mathrm{K}, \mathrm{Ca}$ and $\mathrm{Mg}$ (KUE, CaUE, and MgUE) in eucalypt clones cultivated in seven soil types, with and without the addition of mineral sources of $\mathrm{K}, \mathrm{Ca}$, and $\mathrm{Mg}$.

\begin{tabular}{|c|c|c|c|c|c|}
\hline \multirow{2}{*}{ Source } & \multirow{2}{*}{ DF } & \multicolumn{4}{|c|}{ Mean Squares } \\
\hline & & $\mathbf{H}$ & SD & SDM & RDM \\
\hline Soils (S) & 6 & $861.2^{\star \star}$ & $7.8^{\star \star}$ & $1,851.5 * \star$ & $36.5^{* *}$ \\
\hline Fertilization (F) & 1 & $2,866.1 * \star$ & $5.1 * \star$ & $2,467.5^{* *}$ & $3.7^{\mathrm{ns}}$ \\
\hline$S \times F$ & 6 & $241.1^{\star}$ & $1.8^{*}$ & $66.8^{\text {ns }}$ & $17.5^{\mathrm{ns}}$ \\
\hline Error & 56 & 90.2 & 0.67 & 68.5 & 11.0 \\
\hline $\mathrm{CV}$ & & 10.0 & 6.1 & 12.8 & 27.1 \\
\hline \multirow{2}{*}{ Source } & \multirow{2}{*}{ DF } & \multicolumn{4}{|c|}{ Mean Squares } \\
\hline & & TDM & $\mathbf{K}$ & $\mathrm{Ca}$ & Mg \\
\hline Soils (S) & & $2,393.5^{\star *}$ & $19.2^{* \star}$ & $59.4^{* \star}$ & $9.9 * *$ \\
\hline Fertilization (F) & & $2,559.1 * \star$ & $1,268.0$ ** & $59.7 * \star$ & $6.9 * *$ \\
\hline $\mathrm{S} \times \mathrm{F}$ & & $110.0^{\text {ns }}$ & $25.3 * \star$ & $9.1 *$ & $0.5^{\mathrm{ns}}$ \\
\hline Error & & 63.0 & 3.0 & 3.6 & 0.3 \\
\hline $\mathrm{CV}$ & & 10.3 & 18.4 & 17.1 & 18.7 \\
\hline \multirow{2}{*}{ Source } & \multirow{2}{*}{ DF } & \multicolumn{4}{|c|}{ Mean Squares } \\
\hline & & KA & $\mathrm{CaA}$ & MgA & KUE \\
\hline Soils (S) & & $0.3^{* *}$ & $0.9 * *$ & $0.1 * \star$ & $0.7^{* \star}$ \\
\hline Fertilization (F) & & $9.6^{* \star}$ & $0.0^{\text {ns }}$ & $0.0^{\text {ns }}$ & $3.4^{* *}$ \\
\hline$S \times F$ & & $0.1 * *$ & $0.1 * *$ & $0.0^{\mathrm{ns}}$ & $0.1^{\mathrm{ns}}$ \\
\hline Error & & 0.0 & 0.0 & 0.0 & 0.0 \\
\hline $\mathrm{CV}$ & & 21.31 & 20.6 & 23.4 & 22.9 \\
\hline \multirow{2}{*}{ Source } & \multirow{2}{*}{ DF } & \multicolumn{4}{|c|}{ Mean Squares } \\
\hline & & CaUE & MgUE & A & E \\
\hline Soils (S) & & $0.7 * \star$ & $6.2^{\star \star}$ & $1.6^{\mathrm{ns}}$ & $9.5^{\star \star}$ \\
\hline Fertilization (F) & & $1.6^{* *}$ & $26.5^{* *}$ & $8.9 *$ & $6.4^{*}$ \\
\hline$S \times F$ & & $0.1 * \star$ & $1.3^{*}$ & $3.8^{*}$ & $2.5^{\mathrm{ns}}$ \\
\hline Error & & 0.0 & 0.4 & 1.4 & 1.1 \\
\hline $\mathrm{CV}$ & & 25.78 & 30.8 & 9.9 & 11.9 \\
\hline
\end{tabular}

ns (not significant); * and ** (significant at 5 and $1 \%$ probability, respectively)

\section{Biometric Variables}

When fertilized with $\mathrm{K}, \mathrm{Ca}$, and $\mathrm{Mg}$, plants cultivated in the soils PVd, PAVd, PAd and RQo presented higher $\mathrm{H}$, while plants cultivated in soils PVd and PAd expressed higher values for SD (Table 4). These results can be explained by the lower reserves of $\mathrm{K}, \mathrm{Ca}$, and $\mathrm{Mg}$ in these soils, corroborating with the results observed by Castro et al. (2010) and Amaral et al. (2015) in studies involving the same soils. 
Table 4. Means of plant height $(\mathrm{H})$; stem diameter (SD); concentrations of potassium (K) and calcium (Ca); accumulation of $\mathrm{K}$ and $\mathrm{Ca}(\mathrm{KA}$ and $\mathrm{CaA}$ ) in the shoot dry matter; Mg use efficiency (MgUE) and photosynthetic rate $(A)$ of eucalypt clones cultivated in seven soil classes, with and without the joint addition of mineral sources of $\mathrm{K}, \mathrm{Ca}$ and $\mathrm{Mg}$. Means followed by the same lower case letters in the column and upper case letters in the line do not differ statistically by the Scott-Knott test at 5\% probability.

\begin{tabular}{|c|c|c|c|c|}
\hline \multirow{3}{*}{ Soils } & \multicolumn{2}{|c|}{$\mathrm{H}(\mathrm{cm})$} & \multicolumn{2}{|c|}{ SD (mm) } \\
\hline & With & Without & With & Without \\
\hline & $\mathrm{K}, \mathrm{Ca}$, and $\mathrm{Mg}$ & $\mathrm{K}, \mathrm{Ca}$, and $\mathrm{Mg}$ & $\mathrm{K}, \mathrm{Ca}$, and $\mathrm{Mg}$ & $\mathrm{K}, \mathrm{Ca}$, and $\mathrm{Mg}$ \\
\hline PVd & $102.20 \mathrm{aA}$ & $86.20 \mathrm{cB}$ & $14.40 \mathrm{aA}$ & $12.40 \mathrm{cB}$ \\
\hline PVAd & $98.40 \mathrm{aA}$ & $73.50 \mathrm{cB}$ & $14.00 \mathrm{aA}$ & $13.10 \mathrm{bA}$ \\
\hline PAd & $95.40 \mathrm{aA}$ & $76.60 \mathrm{cB}$ & $13.70 \mathrm{aA}$ & $12.40 \mathrm{cB}$ \\
\hline CXve & $102.00 \mathrm{aA}$ & $97.10 \mathrm{bA}$ & $13.80 \mathrm{aA}$ & $13.90 \mathrm{bA}$ \\
\hline $\mathrm{RRd}$ & $107.00 \mathrm{aA}$ & $98.40 \mathrm{bA}$ & $13.80 \mathrm{aA}$ & $13.40 \mathrm{bA}$ \\
\hline MTo & $107.20 \mathrm{aA}$ & $110.40 \mathrm{aA}$ & $14.60 \mathrm{aA}$ & $13.80 \mathrm{aA}$ \\
\hline \multirow[t]{2}{*}{ RQo } & $95.80 \mathrm{aA}$ & $78.20 \mathrm{cB}$ & $11.60 \mathrm{bA}$ & $11.40 \mathrm{dA}$ \\
\hline & \multicolumn{2}{|c|}{ K ( g kg $\left.^{-1}\right)$} & \multicolumn{2}{|c|}{$\mathrm{Ca}\left(\mathrm{g} \mathrm{kg}^{-1}\right)$} \\
\hline \multirow[t]{2}{*}{ Soils } & With & Without & With & Without \\
\hline & $\mathrm{K}, \mathrm{Ca}$, and $\mathrm{Mg}$ & $\mathrm{K}, \mathrm{Ca}$, and $\mathrm{Mg}$ & $\mathrm{K}, \mathrm{Ca}$, and $\mathrm{Mg}$ & $\mathrm{K}, \mathrm{Ca}$, and $\mathrm{Mg}$ \\
\hline PVd & $17.13 \mathrm{aA}$ & $5.82 \mathrm{aB}$ & $13.47 \mathrm{aA}$ & $14.76 \mathrm{aA}$ \\
\hline PVAd & $13.84 \mathrm{bA}$ & 3.76 bB & $12.08 \mathrm{aA}$ & $12.46 \mathrm{bA}$ \\
\hline PAd & $12.07 \mathrm{cA}$ & $3.69 \mathrm{bB}$ & $8.87 \mathrm{cA}$ & $10.68 \mathrm{bA}$ \\
\hline cxve & $10.07 \mathrm{cA}$ & $6.27 \mathrm{aB}$ & $10.50 \mathrm{bA}$ & $12.14 \mathrm{bA}$ \\
\hline $\mathrm{RRd}$ & $14.11 \mathrm{bA}$ & $6.52 \mathrm{aB}$ & $6.43 \mathrm{dA}$ & $7.77 \mathrm{cA}$ \\
\hline MTo & $11.66 \mathrm{cA}$ & $6.07 \mathrm{aB}$ & 10.57 bB & $16.56 \mathrm{aA}$ \\
\hline \multirow[t]{2}{*}{ RQo } & $17.23 \mathrm{aA}$ & $4.35 \mathrm{bB}$ & $9.71 \mathrm{cA}$ & $10.17 \mathrm{bA}$ \\
\hline & \multicolumn{2}{|c|}{ KA (g plant ${ }^{-1}$ ) } & \multicolumn{2}{|c|}{$\mathrm{CaA}\left(\right.$ g plant $\left.^{-1}\right)$} \\
\hline \multirow[t]{2}{*}{ Soils } & With & Without & With & Without \\
\hline & $\mathrm{K}, \mathrm{Ca}$, and $\mathrm{Mg}$ & $\mathrm{K}, \mathrm{Ca}$, and $\mathrm{Mg}$ & $\mathrm{K}, \mathrm{Ca}$, and $\mathrm{Mg}$ & $\mathrm{K}, \mathrm{Ca}$, and $\mathrm{Mg}$ \\
\hline PVd & $1.53 \mathrm{aA}$ & $0.44 \mathrm{aB}$ & $1.21 \mathrm{aA}$ & $1.11 \mathrm{bA}$ \\
\hline PVAd & $0.98 c A$ & $0.21 \mathrm{bB}$ & $0.86 \mathrm{bA}$ & $0.72 \mathrm{dA}$ \\
\hline PAd & $0.92 \mathrm{cA}$ & $0.20 \mathrm{bB}$ & $0.69 \mathrm{cA}$ & $0.59 \mathrm{dA}$ \\
\hline CXve & $0.90 \mathrm{cA}$ & $0.49 \mathrm{aB}$ & $0.94 \mathrm{bA}$ & $0.96 \mathrm{cA}$ \\
\hline $\mathrm{RRd}$ & $1.38 \mathrm{bA}$ & $0.50 \mathrm{aB}$ & $0.60 \mathrm{cA}$ & $0.60 \mathrm{dA}$ \\
\hline MTo & $1.17 \mathrm{cA}$ & $0.60 \mathrm{aB}$ & $1.06 \mathrm{aB}$ & $1.65 \mathrm{aA}$ \\
\hline \multirow[t]{2}{*}{ RQo } & $1.03 \mathrm{cA}$ & $0.22 \mathrm{bB}$ & $0.58 \mathrm{cA}$ & $0.52 \mathrm{dA}$ \\
\hline & \multicolumn{2}{|c|}{ MgUE } & \multicolumn{2}{|c|}{$\mathrm{A}\left(\mu \mathrm{mol} \mathrm{CO} \mathrm{Cm}^{-2} \mathrm{~s}^{-1}\right)$} \\
\hline \multirow[t]{2}{*}{ Soils } & With & Without & With & Without \\
\hline & $\mathrm{K}, \mathrm{Ca}$, and $\mathrm{Mg}$ & $\mathrm{K}, \mathrm{Ca}$ and $\mathrm{Mg}$ & $\mathrm{K}, \mathrm{Ca}$, and $\mathrm{Mg}$ & $\mathrm{K}, \mathrm{Ca}$, and $\mathrm{Mg}$ \\
\hline PVd & $2.70 \mathrm{cA}$ & $2.00 \mathrm{aA}$ & $11.00 \mathrm{aA}$ & $12.40 \mathrm{aA}$ \\
\hline PVAd & $1.80 \mathrm{dA}$ & $1.40 \mathrm{bA}$ & $10.50 \mathrm{aB}$ & $12.40 \mathrm{aA}$ \\
\hline PAd & $2.70 \mathrm{cA}$ & $0.90 \mathrm{bB}$ & $11.00 \mathrm{aA}$ & $11.90 \mathrm{aA}$ \\
\hline CXve & $2.80 \mathrm{cA}$ & $1.70 \mathrm{aB}$ & $12.30 \mathrm{aA}$ & $10.60 \mathrm{aB}$ \\
\hline $\mathrm{RRd}$ & $4.80 \mathrm{aA}$ & $2.10 \mathrm{aB}$ & $11.50 \mathrm{aA}$ & $12.70 \mathrm{aA}$ \\
\hline MTo & $3.40 \mathrm{bA}$ & $2.30 \mathrm{aB}$ & $12.60 \mathrm{aA}$ & $12.40 \mathrm{aA}$ \\
\hline RQo & $1.50 \mathrm{dA}$ & $0.80 \mathrm{bA}$ & $11.20 \mathrm{aB}$ & $12.70 \mathrm{aA}$ \\
\hline
\end{tabular}


The absence of significant differences between values of plant height $(\mathrm{H})$ when comparing results with and without fertilization in soils CXve, RRd, and MTo (Table 4), likewise for stem diameter (SD) in PVAd, CXve, RRd, MTo, and, RQo (Table 4), demonstrates that the availability of these nutrients in these soils was minimally enough to supply the plants' demands, showing the importance of nutrient reserves to rationalize the nutritional management of the culture.

Such similarity between results leads us to imply that the supply of $\mathrm{K}, \mathrm{Mg}$, and Ca via fertilization for plants cultivated in these soils is causing luxury uptake (Gommers et al., 2005; Marschner, 2012), a phenomenon defined as the uptake of more nutrients than plants demand. Luxury uptake might lead to an accentuated retrieval of nutrients from soil reserves (Alves et al., 1998) by gradually raising plant's uptake demands and eventually making production costly and compromising long-term productivity.

Considering the dry matter analyses in all soils, variables SDM and TDM presented similar behavior, with higher values in plants cultivated in MTo, followed by plants cultivated in CXve and RRd (Figures $1 \mathrm{~A}$ and $\mathrm{E}$ ).

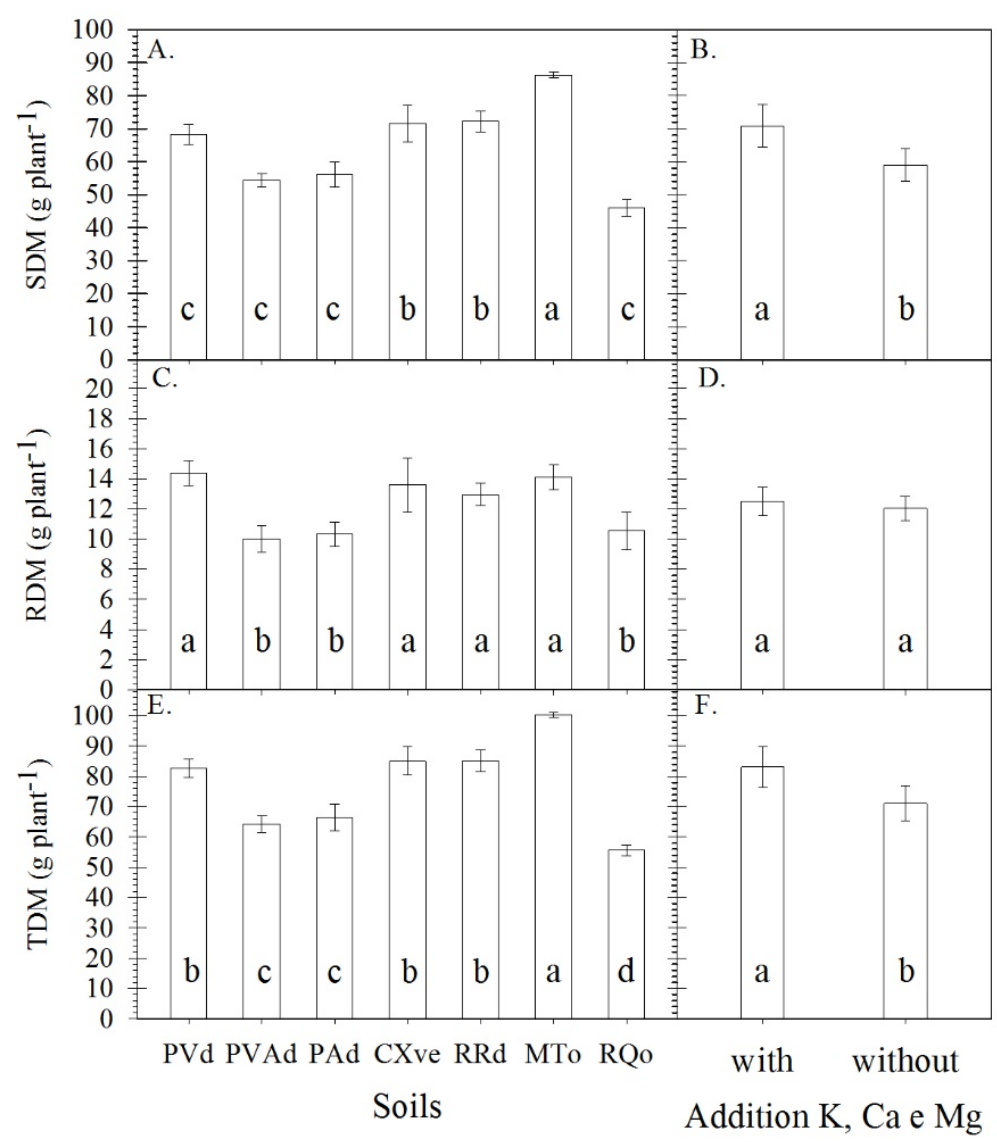

Figure 1. Means of shoot dry matter - SDM (Figure 1A), root dry matter - RDM (Figure 1C) and total dry matter - TDM (Figure 1E) of eucalypt clones cultivated in seven soil classes, with and without the addition of mineral sources of $\mathrm{K}, \mathrm{Ca}$ and $\mathrm{Mg}$ (Figures $1 \mathrm{~B}, \mathrm{D}$ and $\mathrm{F}$ ).

Means followed by the same letters do not differ statistically by the Scott-Knott test at 5\% probability.

Regarding soil fertilization, values for SDM and TDM were higher in plants cultivated in soils that received fertilization (Figures $1 \mathrm{~B}$ and F). The addition of $\mathrm{K}, \mathrm{Ca}$, and $\mathrm{Mg}$ sources did not promote substantial differences in RDM (Figure 1D), since the root system does not have to develop much to acquire soil nutrients.

Variables H, SD, SDM, RDM, and TDM are commonly used as quality indicators and to evaluate the initial development of eucalypt clones (Freitas et al., 2010; Figueiredo et al., 2011; Rodrigues et al., 2012; Rocha et al., 2013; Melo et al., 2014; Medeiros et al., 2016; Ferreira et al., 
2016; Bacha et al., 2017). Higher values for these variables in plants cultivated in MTo, CXve, and RRd reflect an increased availability of $\mathrm{K}, \mathrm{Ca}$, and $\mathrm{Mg}$ due to these soils' mineralogy. Feldspar, mica, and smectite, source minerals of $\mathrm{K}, \mathrm{Ca}$, and $\mathrm{Mg}$ (Kämpf et al., 2009), are predominant in the soils of the studied region (Castro et al., 2010).

\section{Nutritional Variables}

Studies about the efficiency in the use of $\mathrm{K}, \mathrm{Ca}$, and $\mathrm{Mg}$ can guide foresters in adapting the fertilization management of forest plantations according to the soil's potential in providing nutrients to the plants (Battie-Laclau et al., 2016; Rosim et al., 2016). Efficient nutrient use depends on the production of TDM and the concentration of nutrients in the plant's tissues (equation illustrated in the Material and Methods section), as observed by Lima et al. (2005) and Pinto et al. (2011).

Higher accumulation of $K(K A)$ in plants cultivated in all soils that received fertilization (Table 4) reflects the higher values for TDM, according to Figures $1 \mathrm{E}$ and F. Despite higher production of TDM, plants cultivated in MTo fertilized with $\mathrm{K}$, Ca and Mg (Table 4) presented low $\mathrm{Ca}$ accumulation $(\mathrm{CaA})$ due to the lower foliar concentrations of these nutrients in the plant tissue (Table 4).

Higher foliar concentrations of $\mathrm{K}$ (Table 4) in plants cultivated in fertilized soils are a consequence of the increase in the availability of this nutrient. The lower foliar concentrations of Ca in plants cultivated in MTo can be associated to the inhibition of its absorption caused by the higher proportion of $\mathrm{K}$ in the solution, aggravated by this nutrient's low mobility inside the plant.

Highest values for use efficiency of K (KUE) in plants cultivated in MTo (Figure 2A) and Ca (CaUE) in plants cultivated in RRd (Figure 2C) are due to the higher production of TDM (Figure 1E) and the smaller content of this nutrient (Table 4) in plants cultivated in the referred soils. Fertilization statistically changed values of KUE, CaUE and E (Figure 2B, D, and F).

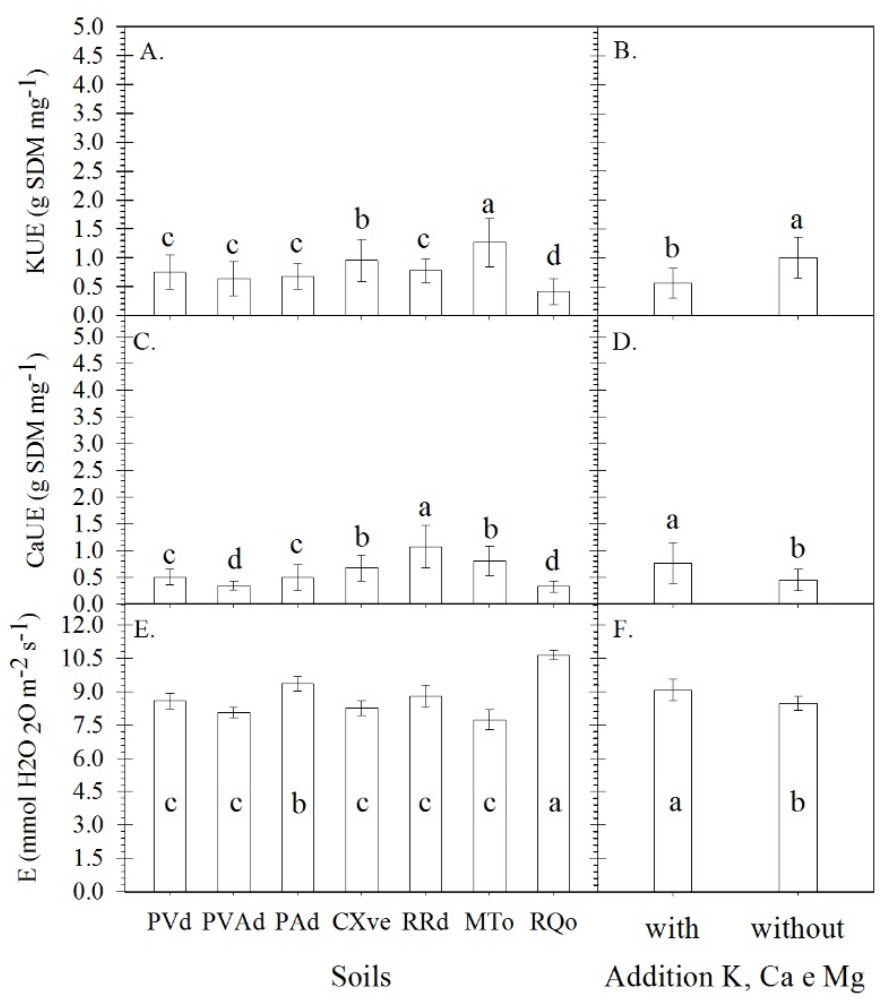

Figure 2. Efficiency in the use of potassium - KUE (Figure 2A), calcium - CaUE (Figure 2C), and transpiration rate - E (Figure $\mathbf{2 E}$ ) for the production of shoot dry matter of eucalypt clones cultivated in seven soil classes, with and without the addition of mineral sources of $\mathrm{K}, \mathrm{Ca}$ and $\mathrm{Mg}$ (Figures 2B, D and F). Means followed by the same letters do not differ statistically by the Scott-Knott test at 5\% probability. 
Comparing results with and without fertilization, KUE was lower in plants cultivated in soils with the addition of $\mathrm{K}, \mathrm{Ca}$, and $\mathrm{Mg}$ (Figure 2B), which can be explained by the higher availability of $\mathrm{K}$ in fertilized soils. Silva et al. (2002) also observed a reduction in use efficiency of $\mathrm{K}$ for eucalypt plants when there was an increase in the availability of this nutrient in the soil.

Higher accumulation of $\mathrm{Mg}(\mathrm{MgA})$ was verified in plants cultivated in MTo, followed by CXve (Figure 3C), and was a consequence of the production of TDM, which was higher in plants cultivated in these soils (Figure 1E). The accumulation of nutrients in the plant's tissue has direct relation with TDM production (Salgado et al., 2016), such that the highest production of TDM favors the higher accumulation of nutrient in the plant tissue.

The higher content of foliar Mg in plants cultivated in CXve and MTo (Figure 3A) can be justified by the higher availability and the larger reserve of this nutrient in these soils. Regarding fertilization, higher values for $\mathrm{Mg}$ content in plants cultivated without fertilization (Figure 3B) can be associated with the interaction between these nutrients in the soil solution. The high availability of $\mathrm{K}$ and $\mathrm{Ca}$ in the soils after fertilization may have inhibited the absorption of $\mathrm{Mg}$ by plants and, consequently, reduced the concentrations of this nutrient in plants cultivated in fertilized soils, illustrating the relevance of understanding the soil's natural potential before dosing fertilizers.

The absence of significant differences in the values of MgUE when comparing results with and without fertilization in plants cultivated in soils PVd, PVAd and RQo (Table 4) can be justified by the production of TDM (Figure 1E) and by the foliar concentration of magnesium (Mg) (Figure 3A). Plants cultivated in these soils presented lower TDM (Figure 1E) and foliar Mg (Figure $3 \mathrm{~A}$ ) values, which are variables involved in the calculation of the plants' nutrient use efficiency. Fertilization did not statistically change the values of MgA (Figure 3C).

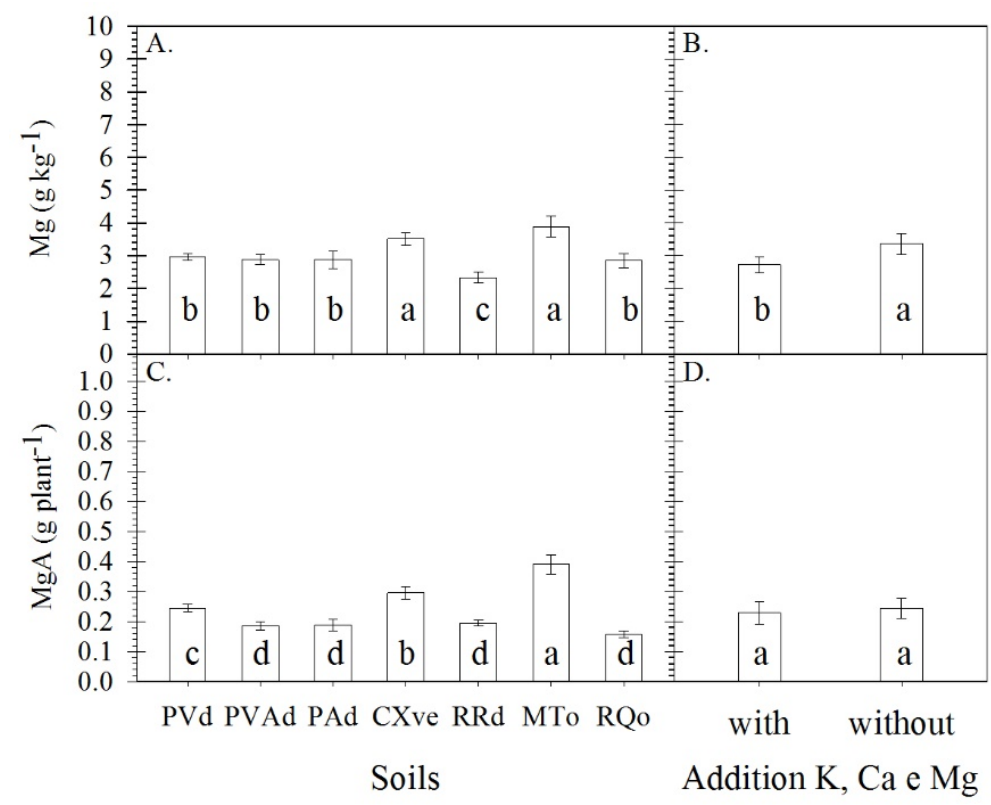

Figure 3. Magnesium content - Mg (Figure 3A) and magnesium accumulation - MgA (Figure $\mathbf{3 C}$ ) in the shoot dry matter of eucalypt clones cultivated in seven soil classes, with and without the addition of mineral sources of $\mathrm{K}, \mathrm{Ca}$ and $\mathrm{Mg}$ (Figures $3 \mathrm{~B}$ and $\mathrm{D}$ ). Means followed by the same letters do not differ statistically by the Scott-Knott test at $5 \%$ probability.

\section{Physiological Variables}

The photosynthetic rate (A), which ranged from 10.5 to $12.7 \mu \mathrm{mol} \mathrm{CO} \mathrm{Cm}^{-2} \mathrm{~s}^{-1}$ (Table 4), is shown by several studies to vary depending on the species (Teixeira et al., 2008), genetic material (Fernandes et al., 2015), plant age, temperature (Turnbull et al., 2007), and nutritional status. The lower values on photosynthetic rate (A) in plants cultivated in CXve, without fertilization (Table 4), could be caused by the availability of nutrients in the soil, especially K (Catuchi et al., 2012), which is associated to photosynthetic rate (Mendes et al., 2013). 
In addition, the imbalance between the concentrations of $\mathrm{K}, \mathrm{Ca}$, and $\mathrm{Mg}$ in the soil solution can also influence the physiological variables of the plants. In CXve, Mg occupies a higher percentage of the cation exchangeable sites compared to $\mathrm{K}$ and $\mathrm{Ca}$, causing the mentioned disequilibrium. However, absorption of $\mathrm{K}$ can be inhibited when there is high availability of cations, such as Ca and Mg in the soil solution (Marschner, 2012), which compete with K for the absorption sites of the cells (Foloni \& Rosolem, 2008).

The higher transpiration rate (E) in plants cultivated in RQo, followed by plants cultivated in PAd (Figure 3E), are probably associated with the lower availability of $\mathrm{K}$ in these soils (Amaral, 2016), corroborating the results found by Teixeira et al. (2008) and Catuchi et al. (2012). Potassium exerts an essential role in countless metabolic and physiologic processes, acting in the osmotic control of the cells (Mendes et al., 2013). This nutrient is responsible for the opening and closing of the stomata, controlling water transportation and, consequently, nutrient absorption (Marschner, 2012). In addition, it is necessary to consider the influence of soil texture on transpiration rate, since RQo had the lowest percentage of clay among the studied soils (Amaral, 2016).

\section{Principal Component Analysis}

The principal component analysis (PCA) applied to the variables (Figure 4A) and treatments (Figure 4C) demonstrated that components PC1 and PC2 explain 59.97\% of the total variation in plants cultivated with $\mathrm{K}, \mathrm{Ca}$, and $\mathrm{Mg}$. For plants cultivated without fertilization, PCA showed that components PC1 and PC2 explain 73\% of the total variation (Figures 4B and D).

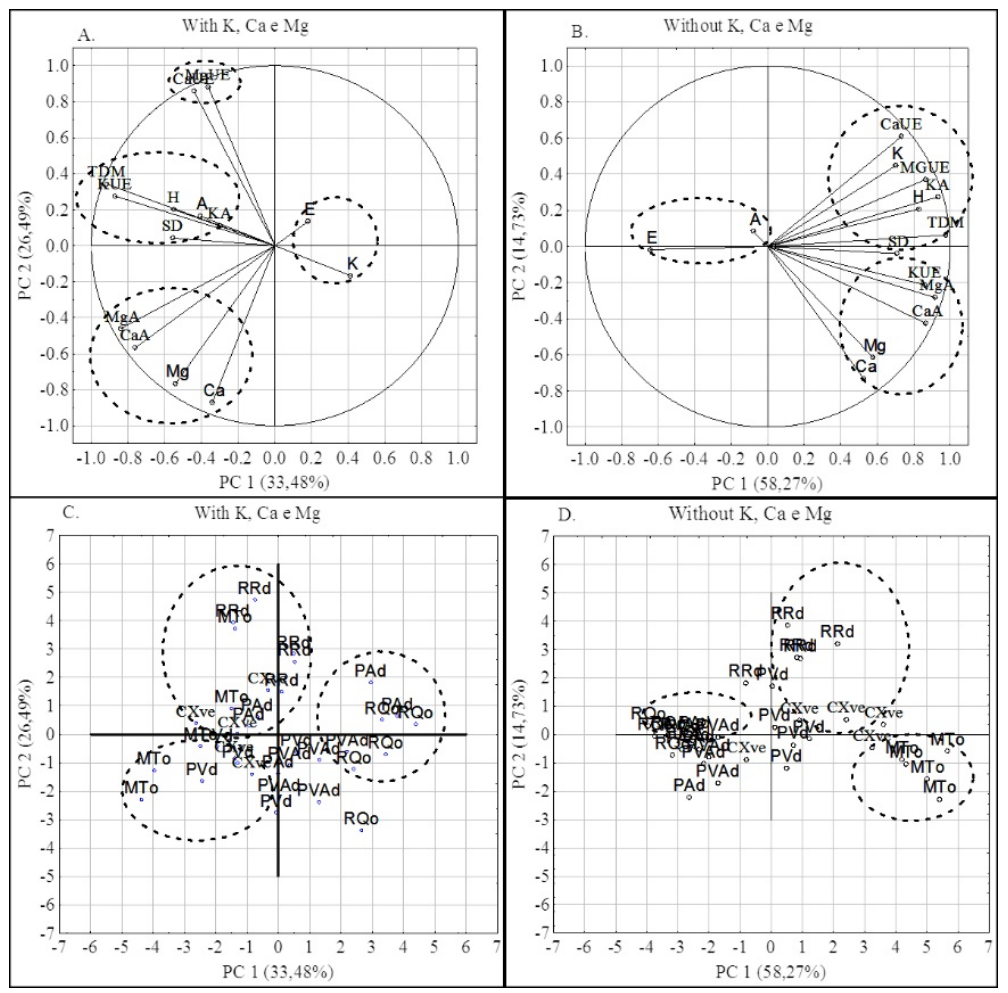

Figure 4. Distribution of the biometric, nutritional and physiological variables of eucalypt clones (Figures $4 \mathrm{~A}$ and $\mathrm{B}$ ) and of the seven soil classes (Figures $4 \mathrm{C}$ and $\mathrm{D}$ ) by the principal component analysis performed in samples cultivated with and without the addition of mineral sources of $\mathrm{K}, \mathrm{Ca}$ and $\mathrm{Mg}$.

In plants cultivated in fertilized soils (Figure 4A), the variables TDM, KUE, $H, A$, KA, and SD showed greater relationship to RRd, CXve, and PAd (Figure 4C). Variables MgA, CaA, foliar concentrations of $\mathrm{Mg}$ and $\mathrm{Ca}$ (Figure 4A), were related to soils MTo and PVd (Figure 4C). Variables E and K (Figure 4A) were more dependent on PAd and RQo (Figure 4C).

Plants cultivated in soils without the addition of $\mathrm{K}, \mathrm{Ca}$, and $\mathrm{Mg}$ pointed to $\mathrm{CaUE}, \mathrm{K}, \mathrm{Ca}$, MgUE, KA, H, SD, and TDM (Figure 4B) as being more dependent on soils RRd, PVd and CXve 
(Figure 4D). The variables KUE, MgA, CaA, foliar Ca, and Mg (Figure 4B) were more dependent on MTo (Figure 4D). The variables E and A (Figure 4B) had a high dependency on RQo and PAd (Figure 4D).

Soils RRd and CXve are naturally good mineral sources as they are soils yet in the first stages of weathering and therefore are expected to hold greater primary mineral content, explaining why they relate to so many biometric variables. MTo are soils rich in organic matter, which grants this soil class a higher cation exchange capacity and makes it a great fountain of nutrients, justifying its closer relationship to nutritional variables (Figure 4).

Moreover, PAd and PVd, despite possessing a lower primary mineral content, are classes known to present greater cation exchange capacity compared to the others studied here (chiefly due to their higher clay content), having a better efficiency in holding nutrients within their structure and making them available for plants.

Hence, the higher availability of $\mathrm{K}, \mathrm{Ca}$, and $\mathrm{Mg}$ in RRd, CXve, and MTo resulted in higher plant uptake and, thus, explains the higher accumulation of these nutrients. Consequently, the high availability of these nutrients contributed to the better development of plants cultivated in these soils, shown in Figure 4 by their relationship with biometric values even without the addition of nutrients. Conversely, RQo and PAd are deficient in $\mathrm{K}, \mathrm{Ca}$, and $\mathrm{Mg}$, therefore plants cultivated without fertilization develop higher transpiration rates, as $\mathrm{K}$ acts in the control of opening and closing the stomata and, consequently, is related to water loss (Marschner, 2012; Mendes et al., 2013).

\section{CONCLUSIONS}

Eucalyptus plants' development do not improve significantly after fertilization when cultivated in soils with high reserves of $\mathrm{Ca}, \mathrm{Mg}$, and $\mathrm{K}$, showing that plant growth is under direct influence of the soil's nutrient reserves.

It is therefore important in forestry to understand how soil mineral reserves affects plants' nutrient uptake as this knowledge can lead to an optimal fertilization management and consequently to the reduction of production costs.

\section{ACKNOWLEDGMENTS}

The authors thank the Conselho Nacional de Desenvolvimento Científico e Tecnológico CNPq, the Fundação de Amparo à Pesquisa do Estado de Minas Gerais - FAPEMIG and the Coordenação de Aperfeiçoamento de Pessoal de Nível Superior - CAPES, for the financial support.

\section{REFERENCES}

Alves, A. C., Brauner, J. L., Cordeiro, D. S., Zonta, E. P., \& Correa, L. A. V. (1998). Exigências nutricionais em potássio, cálcio e magnésio do sorgo sacarino. Pesquisa Agropecuária Brasileira, 23(5), 529-536.

Alves, M. J. F., Melo, V., Reissmann, C. B., \& Kaseker, J. F. (2013). Reserva mineral de potássio em Latossolo cultivado com Pinus taeda L. Revista Brasileira de Ciência do Solo, 37(6), 1599-1610. http://dx.doi.org/10.1590/S0100-06832013000600016.

Amaral, F. H. C. (2016). Compartimentos de K, Ca e Mg em solos e sua relação com o crescimento inicial, fisiologia e produtividade do eucalipto (Tese de doutorado). Universidade Federal de Lavras, Lavras.

Amaral, F. H. C., Furtini Neto, A. E., Curi, N., Inda, A. V., \& Araújo, E. F. (2015). Produtividade de Eucalyptus grandis e sua relação com a cinética de liberação de macronutrientes. Scientia Forestalis, 43(108), 979-991. http://dx.doi.org/10.18671/scifor.v43n108.21.

Amaral, J. F. T., Martinez, H. E., Laviola, B. G., Fernandes Filho, E. I., \& Cruz, C. D. (2011). Eficiência de utilização de nutrientes por cultivares de cafeeiro. Ciência Rural, 41(4), 621-629. http://dx.doi.org/10.1590/S0103-84782011005000027.

Andrade, M. C. N., Minhoni, M. T. A., Sansígolo, C. A., Zied, D. C., \& Sales-Campos, C. (2011). Estudo comparativo da constituição nutricional da madeira e casca de espécies e clones de eucalipto visando o cultivo de shiitake em toras. Revista Árvore, 35(2), 183-192.

http://dx.doi.org/10.1590/S0100-67622011000200002. 
Bacha, A. L., Martins, P. F. R. B., Alves, P. L. C. A., \& Paula, R. C. (2017). Trinexapac-ethyl causes stimulatory effect on eucalyptus initial growth under nutritional deficiency. Canadian Journal of Forest Research, 48(1), 94-100. http://dx.doi.org/10.1139/cjfr-2017-0245.

Battie-Laclau, P., Delgado-Rojas, J. S., Christina, M., Nouvellon, Y., Bouillet, J. P., Piccolo, M. C., Moreira, M. Z., Gonçalves, J. L. de M., Roupsard, O., \& Laclau, J. P. (2016). Potassium fertilization increases wateruse efficiency for stem biomass production without affecting intrinsic water-use efficiency in Eucalyptus grandis plantations. Forest Ecology and Management, 364, 77-89. http://dx.doi.org/10.1016/j.foreco.2016.01.004.

Caldeira, M. V. W., Rondon Neto, R. M., \& Schumacher, M. V. (2004). Eficiência do uso de micronutrientes e sódio em três procedências de acácia-negra (Acacia mearnsii de Wild.). Revista Árvore, 28(1), 39-47. http://dx.doi.org/10.1590/S0100-67622004000100006.

Castro, P. P., Curi, N., Furtini Neto, A. E., Resende, A. V., Guilherme, L. R. G., Menezes, M. D., Araújo, E. F., Freitas, D. A. F., Mello, C. R., \& Silva, S. H. G. (2010). Química e mineralogia de solos cultivados com eucalipto (Eucalyptus spp.). Scientia Forestalis, 38, 645-657.

Catuchi, T. A., Guidorizzi, F. V. C., Guidorizi, K. A., \& Barbosa, A. (2012). Physiological responses of soybean cultivars to potassium fertilization under different water regimes. Pesquisa Agropecuária Brasileira, 47, 519-527. http://dx.doi.org/10.1590/S0100-204X2012000400007.

Empresa Brasileira de Pesquisa Agropecuária - EMBRAPA. (2009). Manual de análises químicas de solos, plantas e fertilizantes (2. ed.). Brasília: Embrapa Informação Tecnológica.

Empresa Brasileira de Pesquisa Agropecuária - EMBRAPA. (2013). Sistema brasileiro de classificação de solos (3. ed.). Brasilia: Embrapa Informação Tecnológica.

Faria, G. E., Barros, N. F., Cunha, V. L. P., Martins, I. S., \& Martins, R. C. C. (2008). Avaliação da produtividade, conteúdo e eficiência de utilização de nutrientes em genótipos de Eucalyptus spp. no Vale do Jequitinhonha, MG. Ciência Florestal, 18(3), 363-373. http://dx.doi.org/10.5902/19805098448.

Fernandes, E. T., Cairo, P. A. R., \& Novaes, A. B. (2015). Respostas fisiológicas de clones de eucalipto cultivados em casa de vegetação sob deficiência hídrica. Ciência Rural, 45(1), 29-34. http://dx.doi.org/10.1590/0103-8478cr20120152.

Ferreira, D. F. (2014). Sisvar: A guide for its bootstrap procedures in multiple comparisons. Ciência e Agrotecnologia, 38(2), 109-112. http://dx.doi.org/10.1590/S1413-70542014000200001.

Ferreira, G. L., Saraiva, D. T., Queiroz, G. P., Silva, D. V., Pereira, G. A. M., Ferreira, L. R., Oliveira Neto, S. N., \& Mattiello, E. M. (2016). Eucalypt growth submitted to management of Urochloa spp. Planta Daninha, 34(1), 99-107. http://dx.doi.org/10.1590/S0100-83582016340100010.

Figueiredo, F. A. M. M. A., Carneiro, J. G. A., Penchel, R. M., Barroso, D. G., \& Daher, R. F. (2011). Efeito das variações biométricas de mudas clonais de eucalipto sobre o crescimento no campo. Revista Árvore, 35(1), 1-11. http://dx.doi.org/10.1590/S0100-67622011000100001.

Foloni, J. S. S., \& Rosolem, C. A. (2008). Produtividade e acúmulo de potássio na soja em função da antecipação da adubação potássica no sistema plantio direto. Revista Brasileira de Ciência do Solo, 32(4), 1549-1561. http://dx.doi.org/10.1590/S0100-06832008000400019.

Freitas, T. A. S., Barroso, D. G., Souza, L. S., Carneiro, J. G. A., \& Paulino, G. M. (2010). Produção de mudas de eucalipto com substratos para sistema de blocos. Revista Árvore, 34(5), 761-770. http://dx.doi.org/10.1590/S0100-67622010000500001.

Gommers, A., Thiry, Y., \& Delvaux, B. (2005). Rhizospheric mobilization and plant uptake of radiocesium from weathered soils: I. Influence of potassium depletion. Journal of Environmental Quality, 34(6), 2167-2173. PMid:16275717. http://dx.doi.org/10.2134/jeq2004.0406.

Kämpf, N., Curi, N., \& Marques, J. J. (2009). Óxidos de alumínio, silício, manganês e titânio. In V. F. Melo \& L. R. F. Alleoni (Eds.), Química e mineralogia do solo (Cap. 9, pp. 573-610). Viçosa: Sociedade Brasileira de Ciência do Solo.

Köppen, W. P. (1931). Grundriss der klimakunde. Berlin: W. Guyter. http://dx.doi.org/10.1515/9783111667751.

Leite, F. P., Silva, I. R., Novais, R. F., Barros, N. F., \& Neves, J. C. L. (2010). Alterations of soil chemical properties by eucalyptus cultivation in five regions in the Rio Doce Valley. Revista Brasileira de Ciência do Solo, 34(3), 821-831. http://dx.doi.org/10.1590/S0100-06832010000300024.

Lima, A. M. N., Neves, J. C. L., Silva, I. R., \& Leite, F. P. (2005). Cinética de absorção e eficiência nutricional de $\mathrm{K}^{+}, \mathrm{Ca}^{2+}$ e $\mathrm{Mg}^{2+}$ em plantas jovens de quatro clones de eucalipto. Revista Brasileira de Ciência do Solo, 29(6), 903-909. http://dx.doi.org/10.1590/S0100-06832005000600008. 
Malavolta, E. (1980). Elementos de nutrição mineral de plantas (1. ed.). São Paulo: Agronômica Ceres. Marschner, H. (2012). Mineral nutrition of higher plants (3rd ed.). London: Elsevier.

Medeiros, W. N., Melo, C. A. D., Tiburcio, R. A. S., da Silva, G. S., Machado, A. F. L., Santos, L. D. T., \& Ferreira, F. A. (2016). Initial growth and nutrient concentration in Eucalyptus urophylla x Eucalyptus grandis clones under weed interference. Ciência Florestal, 26(1), 147-157.

Melo, L. A., Pereira, G. A., Moreira, E. J. C., Davide, A. C., Silva, E. V., \& Teixeira, L. A. F. (2014). Crescimento de mudas de Eucalyptus grandis e Eremanthus erythropappus sob diferentes formulações de substrato. Floresta e Ambiente, 21(2), 234-242. http://dx.doi.org/10.4322/floram.2014.028.

Mendes, H. S. J., Paula, N. F., Scarpinatti, E. A., \& Paula, R. C. (2013). Respostas fisiológicas de genótipos de Eucalyptus grandis x E. urophylla à disponibilidade hídrica e adubação potássica. Cerne, 19(4), 603611. http://dx.doi.org/10.1590/S0104-77602013000400010.

Pinto, S. I., Furtini Neto, A. E., Neves, J. C. L., Faquin, V., \& Moretti, B. S. (2011). Eficiência nutricional de clones de eucalipto na fase de mudas cultivados em solução nutritiva. Revista Brasileira de Ciência do Solo, 35(2), 523-533. http://dx.doi.org/10.1590/S0100-06832011000200021.

Rocha, J. H. T., Pietro, M. R., Borelli, K., Backes, C., \& Neves, M. B. (2013). Produção e desenvolvimento de mudas de eucalipto em função de doses de fósforo. Cerne, 19(4), 535-543. http://dx.doi.org/10.1590/S0104-77602013000400002.

Rodrigues, F. A. V., De Barros, N. F., Neves, J. C. L., Alvarez, V. H., \& Novais, R. F. (2012). Disponibilidade de zinco para mudas de eucalipto em solos de Cerrado. Revista Brasileira de Ciência do Solo, 36(4), 1249-1257. http://dx.doi.org/10.1590/S0100-06832012000400019.

Rosim, C. C., Hsing, T. Y., \& Paula, R. C. (2016). Nutrient use efficiency in interspecific hybrids of eucalypt. Ciência Agronômica, 47(3), 540-547. http://dx.doi.org/10.5935/1806-6690.20160065.

Salgado, F. H. M., Moreira, F. M. S., Paulino, H. B., Siqueira, J. O., \& Carneiro, M. A. C. (2016). Arbuscular mycorrhizal fungi and mycorrhizal stimulant affect dry matter and nutrient accumulation in bean and soybean plants. Pesquisa Agropecuária Tropical, 46(4), 367-373. http://dx.doi.org/10.1590/1983$40632016 \mathrm{v} 4640282$.

Silva, S. R., Barros, N. F., Novais, R. F., \& Pereira, P. R. G. (2002). Eficiência nutricional de potássio e crescimento de eucalipto influenciado pela compactação do solo. Revista Brasileira de Ciência do Solo, 26(4), 1001-1010. http://dx.doi.org/10.1590/S0100-06832002000400018.

Teixeira, P. C., Gonçalves, J. L. M., Arthur Junior, J. C., \& Dezordi, C. (2008). Eucalyptus sp. seedling response to potassium fertilization and soil water. Ciência Florestal, 18(1), 47-63. http://dx.doi.org/10.5902/19805098510.

Turnbull, T. L., Adams, M. A., \& Warren, C. R. (2007). Increased photosynthesis following partial defoliation of field-grown Eucalyptus globulus seedlings is not caused by increased leaf nitrogen. Tree Physiology, 27(10), 1481-1492. PMid:17669738. http://dx.doi.org/10.1093/treephys/27.10.1481.

Vettori, L. (1969). Métodos de análise do solo (Boletim Técnico, No. 7). Rio de Janeiro: Equipe de Pedologia e Fertilidade do Solo.

Authors' contributions: FHCA: writing - original draft, conceptualization, formal analysis, methodology; AEFN: conceptualization, supervision; EFA: conceptualization, supervision; AVI: conceptualization, supervision; MM: writing - original draft, writing - review \& editing; NC: project administration, supervision, conceptualization, writing - review \& editing. 